Supporting Information

\title{
Understanding of the Biomedical Effects of the Self-assembled Tetrahedral DNA Nanostructure on Living Cells
}

Qiang Peng, Xiao-Ru Shao, Jing Xie, Si-Rong Shi, Xue-Qin Wei, Tao Zhang, Xiao-Xiao Cai, Yun-Feng Lin*

State Key Laboratory of Oral Diseases, West China Hospital of Stomatology, Sichuan University, Chengdu 610041, China.

*Correspondence:

Y.F. Lin, Tel: 862885503487

Fax: 862885503487

Email: yunfenglin@scu.edu.cn 


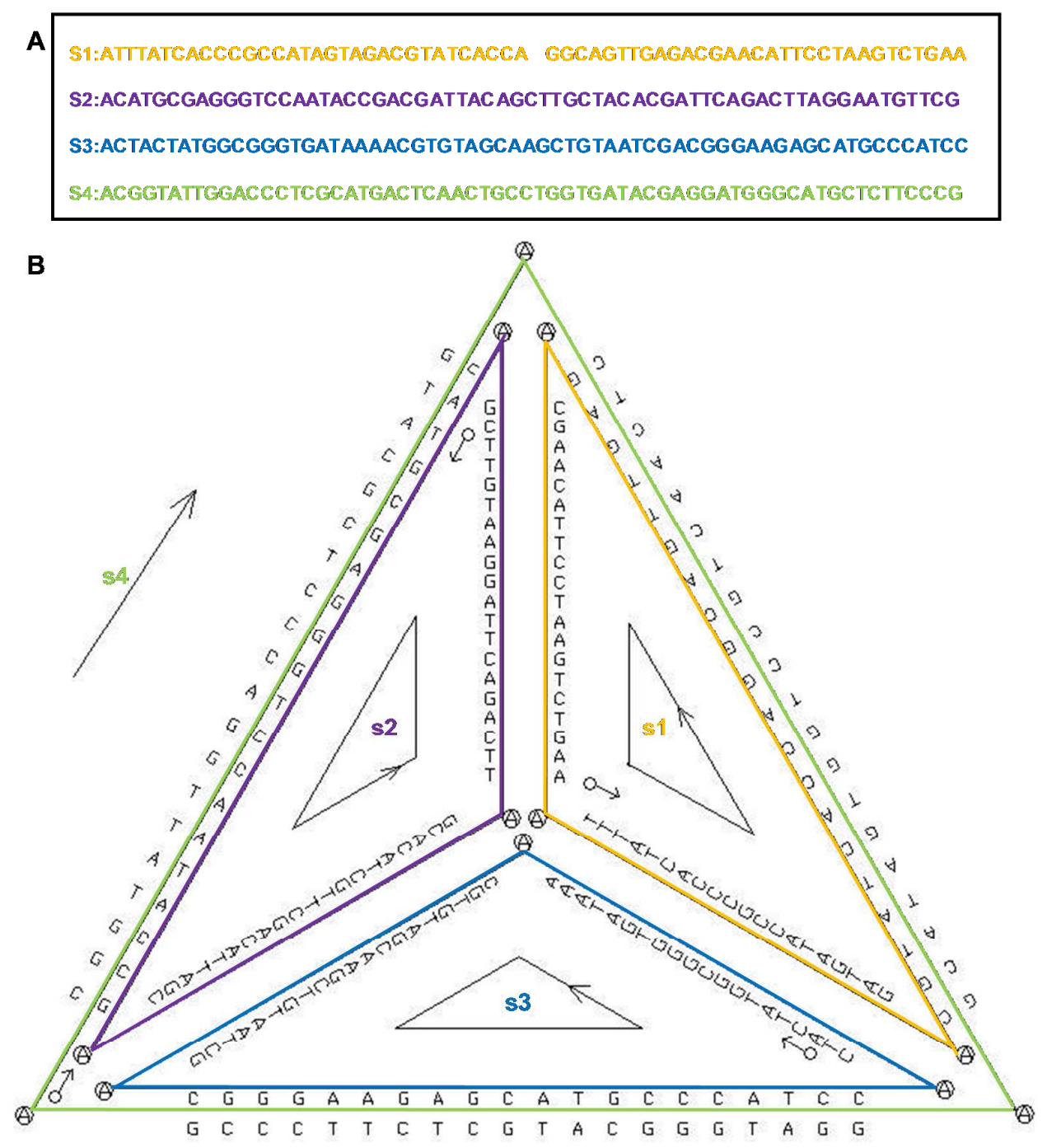

Figure S1. Detailed information of TDN base paring. A) The sequence of four ssDNA; B) The detailed description of each surface and base paring of TDN. 

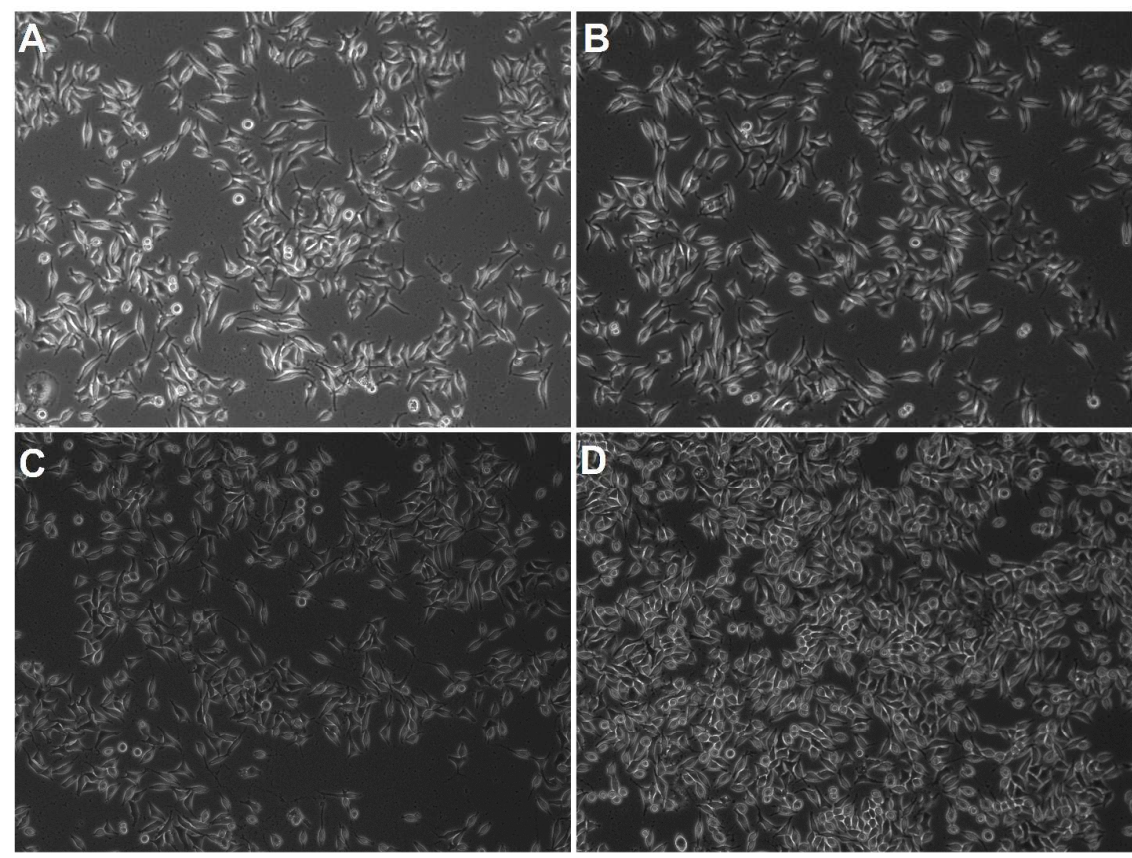

Figure S2. Micrographs of L929 cells before and after exposure to TDN (250 nM). A)

Control, 0 h; B) TDN, 0h; C) Control, 24 h; D) TDN, 24 h. 


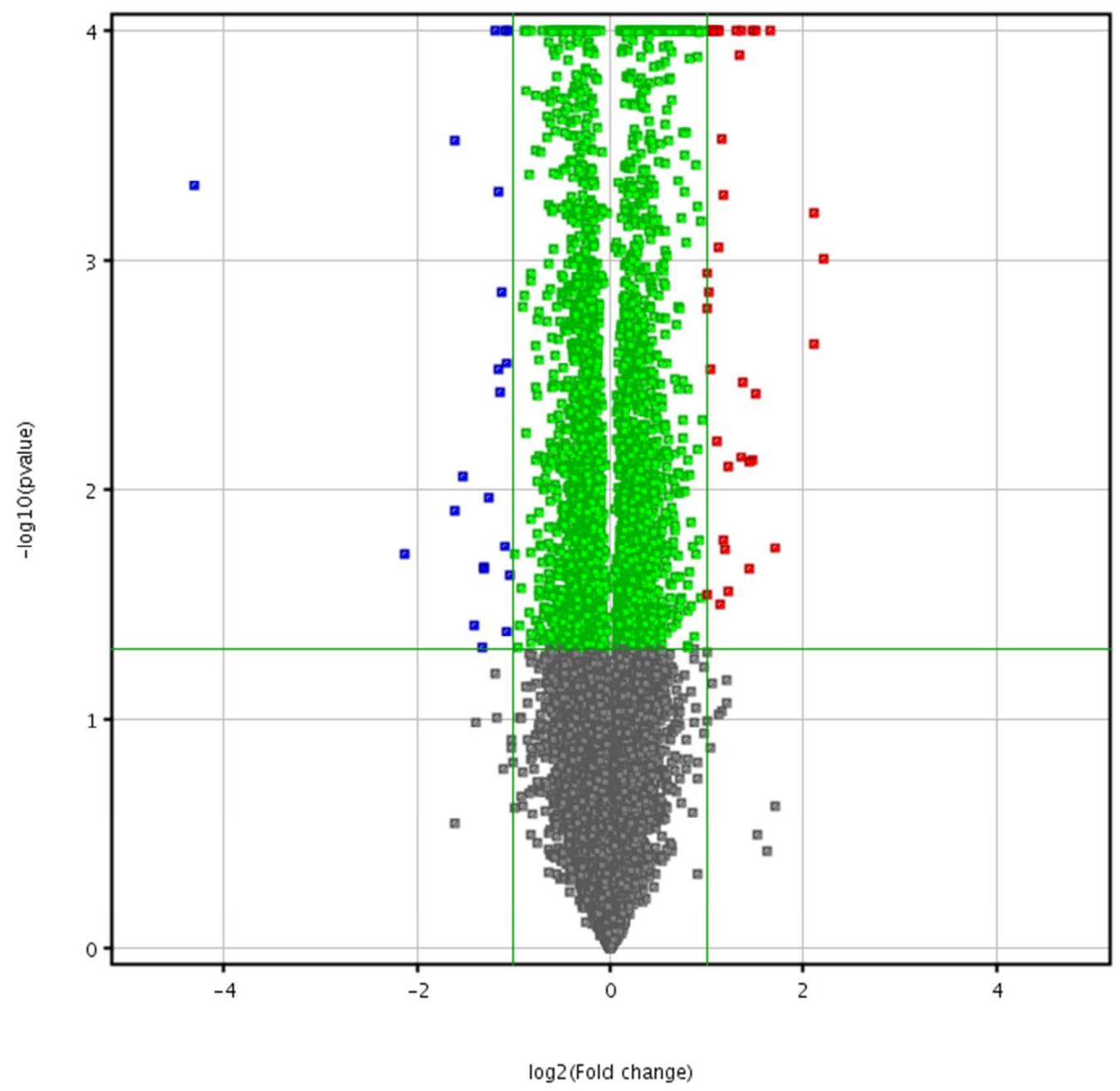

Figure S3. Volcano plot of global gene expression of L929 cells upon exposure to TDN (250 nM). Red points indicate the up-regulated genes with $p \leq 0.05$ as well as fold change $\geq 2$. Blue points indicate the down-regulated genes with $p \leq 0.05$ as well as fold change $\geq 2$. 


\begin{tabular}{|c|c|c|c|}
\hline Control & TDN & Control & TDN \\
\hline Mean G1 = 20.7 & Mean $\mathbf{G 1}=\mathbf{2 8 . 8}$ & Mean G1 = 67.9 & Mean G1 = 68.5 \\
\hline CV G1 = 4.09 & CV G1 = 4.98 & CV G1 = 4.56 & CV G1 = 8.7 \\
\hline$\%$ G1 = 73.5 & $\%$ G1 = 57.6 & $\% G 1=83.9$ & $\% G 1=78.4$ \\
\hline Mean G2 = 51.7 & Mean $\mathrm{G}_{2}=56.1$ & Mean G2 = 132 & Mean G2 = 142 \\
\hline CV G2 = 4.1 & CV G2 $=4.98$ & $C V$ G2 $=4.56$ & CV G2 $=8.7$ \\
\hline$\% G 2=14.9$ & $\% G 2=10.5$ & $\% G 2=13.7$ & $\% G 2=0.682$ \\
\hline$\% S=11.5$ & $\% S=31.9$ & $\% S=2.35$ & $\% S=21$ \\
\hline G2/G1 = 1.939 & G2/G1 = 1.949 & G2/G1 = 1.947 & $\mathrm{G} 2 / \mathrm{G} 1=2.073$ \\
\hline Chi Sq. $=12.6$ & Chi Sq. $=6.44$ & Chi Sq. $=2.88$ & Chi Sq. = 3.51 \\
\hline Cell No. $=19055$ & Cell No. $=20000$ & Cell No. $=20000$ & Cell No. $=20000$ \\
\hline
\end{tabular}

Figure S4. Detailed data about cell cycle of L929 cells after treated by TDN (250 $n M)$. 